\title{
Effects of Culinary Methods on The Proximate Composition of an Edible Insect (Rhynchophorus Phoenicis) Larvae Obtained From Bayelsa State, Nigeria
}

\author{
D. P. Markmanuel and Jackson Godwin
}

\begin{abstract}
This study investigated the effects of culinary methods (boiling and frying) on the proximate composition of an edible insect commonly known as African Palm Weevil (R. phoenicis) Larva(e). The proximate composition (moisture, ash, protein, crude fibre, fat and carbohydrate contents) were determined using standard methodology of the Association of Analytical Chemists (AOAC). Boiling increased the moisture and ash content but, decreased the protein, fat, carbohydrate $(p>0.05)$ and the fibre content compared to the raw sample. On the other hand, frying increased the protein and ash contents $(p<0.05)$ but decreased the moisture, fat, carbohydrate and fibre contents compared to the raw. The decrease in moisture content led to a corresponding increase in the protein, and ash contents of the fried sample, which indicates high protein and mineral levels of the larvae. Also, the lowest moisture content recorded in the fried sample compared to the raw and boiled sample was an indication of reduction of microbial spoilage, and longer storage shelf life of this edible larva. Therefore, frying is recommended as the best culinary method for healthy diet.
\end{abstract}

Index Terms - Edible insects, Rhynchophorus phoenicis, culinary methods, proximate analysis.

\section{INTRODUCTION}

Insects are class of animals that have a chitinous exoskeleton, a three-body part (head, thorax and abdomen), three pairs jointed legs, compound eyes and two antennae. They are classified within the arthropod group and are among the most diverse groups of animals on the planet[1]. The exoskeleton protect them from the environment. They are the only winged invertebrates. They are cold-blooded and undergo metamorphosis to be able to adapt to seasonal variations. Other common features shared by most kinds of insects include ocelli located on the head, a pair of antennae, mouthparts consisting of a labrum, a pair of mandibles, a pair of maxillae, labium and a tongue-like hypopharynx.

Insects can be found in almost all ecosystems such as terrestrial, fresh water and marine habitats (e.g ponds, dried deserts, farm land or field etc). Their feeding habits vary similarly, for example, caterpillars feed on foliage of vegetation, witchetty grubs feed on roots, cicadas live and feed on branches of trees, African palm weevils live and feed on trunk of trees while dung beetles thrive in soils etc [2]. Insects are fundamental part of the ecosystem, and are

Published on August 3, 2020.

D. P. Markmanuel, Niger Delta University, Nigeria. (corresponding e-mail: douyemarkmanuel@gmail.com)

Jackson Godwin, Niger Delta University, Nigeria. inculcalably valuable to man and other biological organisms (especially plants). Often, insects are viewed in negative contexts (especially as pest). However, the positive roles of insects to man and other biological organisms as well as the environment cannot be overemphasized. Some of these roles include;

- Plant production: over 100,000 pollinator species have been identified worldwide [1].

- Waste biodegradation: e.g. Beetle larvae, flies, ants and termite clear up dead plant matter, breaking down organic matter until it is fit to be consumed by fungi and bacteria. They also aid the decomposition of organic matter materials thereby facilitating the recycling of carbon, nitrogen, and other essential nutrients [1].

- Insects are very good source of food which provides man with the basic nutrient requirement such as protein, fat, minerals and vitamins. E.g calcium, iron and zinc, they form a major part of traditional and natural diet [3].

- Beside food, insects also provide man with valuable products such as honey and silk. According to FAO[4] reports, over 1.2 million tonnes of commercial honey are produced annually, while silk worms produce more than 90,000 tonnes of silk [5].

The consumption of insect by man is not a new concept in many parts of the world today. For example in African and Australia, beetle larvae and ants are considered as parts of their subsistence diet prepared either boiled or crispy-fried. Also crispy-fried locusts and beetles are eaten in Thailand. It is estimated that insect eating is regularly practised by not less than 2 billion people worldwide, and more than 1900 insect species have been documented in literature as edible, which most of them are in tropical countries [1]. However, most commonly eaten insect groups are beetles, caterpillars, bees, wasps, ants, grasshoppers, locusts, crickets, cicadas, leaf and plant hoppers, scale insects and true bugs, termites, dragonflies and flies.

In Nigeria, Niger Delta region in particular, one of the most common edible insects is the Rhynchophorus phoenicis larva commonly known as the African palm weevil. This is a species of beetles that belong to the family of curculionide. The larvae are cherished as food in many African communities (Nigeria in particular). In Nigeria, this larvae are consumed by so many tribes examples Ijaw, Yoruba, Igbo and in the Niger Delta region these edible larvae are seen hawked by vendors along highway, streets and markets in states such as Bayelsa, Delta, Rivers, Edo and Akwa Ibom [6]. 
Previously, the edible palm weevil larvae were eaten as bush delicacy among local farmers in rural communities. But now, it is made available for commercial purposes and are sold in large quantities in rural and urban markets. They are either consumed raw, or processed, (boiled, roasted or fried) [7]. Since these larvae provide cheap sources of animal proteins, minerals, vitamins and energy compared to the conventional animal proteins, minerals and vitamins sources, their consumption has been on the increased. This has motivated many researchers to investigate the proximate composition and pollution levels in these edible beetle larvae [7], [8] - [13]. However, these studies fail to evaluate the common culinary practices such as boiling and frying which may affect the proximate composition of these edible larvae. It is against this background that the common culinary methods, boiling and frying were chosen in order to determine their effects on the proximate composition of $R$. phoenicis larvae.

\section{MATERIALS AND METHODS}

\section{A. Study Area}

Bayelsa State is amongst the six states that make up Nigeria's South-South geopolitical zone. The state is geographically located within latitude $04^{0} 15^{\prime \prime}$ North, $05^{0} 23$ South and longitude $05^{0} 22^{\prime}$ West and $06^{0} 45^{\prime}$ "East.Bayelsa State lies in the heaviest rainfall area in Nigeria with heavy rain forest and a short dry season (from November to March). The state is a picturesque tropical rain forest with an area of about 21,110 square kilometers. Bayelsa State shares boundaries with Delta State in the North, River State in the East and the Atlantic in the West and South.

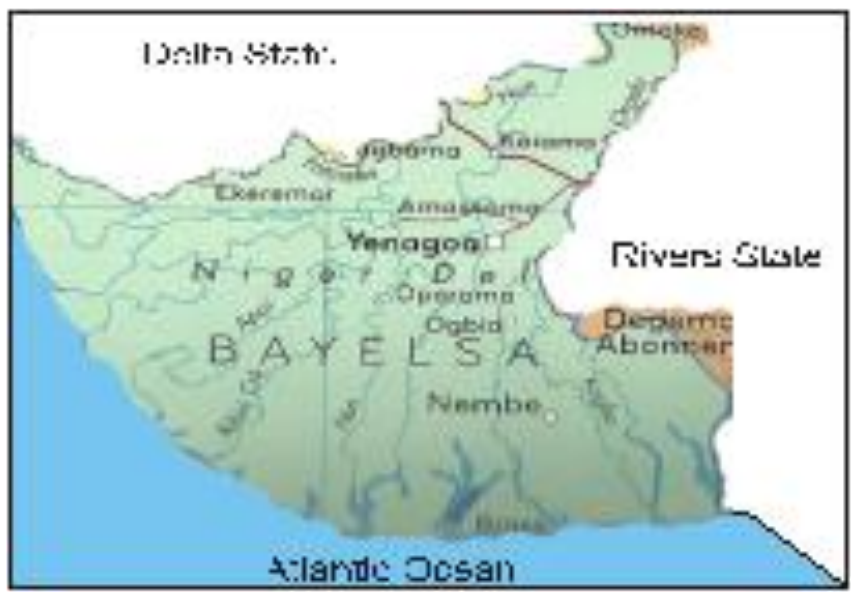

Fig 1. Map Showing Sample Area

Bayelsa State has a riverine and estuarine setting. Many communities are almost/or in most cases surrounded by water making them inaccessible by road. There are four main languages in Bayelsa State, these include: Izon, Nembe, Ogbia and Epie-Atissa. The major occupations in the state are fishing, farming, palm oil milling, palm wine tapping, local gin making, trading, carving and weaving. The State's vegetation is characterized by mangrove forest and thick force with arable lands for cultivation. The state is also one of the coastal area of Nigeria where there is massive oil exploitation and exploration, accounting over $30 \%$ of the Nigerian oil production. There are hundreds of oil well and flow stations across the state. However, the sampling area was Amassoma.

Amassoma is located at Bayelsa central geo-political zone and it is approximately $30 \mathrm{~km}$ away from the state capital city, Yenagoa. The town is situated at 4.970 North latitude, $6.11^{0}$ East longitude, and 79 metres elevation above the sea level. Two third of the land is surrounded by water and is the host community of the Niger Delta University [14]. The palm weevil ( $R$. phoenicis) larvae are normally abundant during the dry season and is collected by local farmers.

\section{B. Sample Collection and Preparation}

$R$. phoenicis larvae were purchased from local farmers in Amassoma, Southern Ijaw Local Government Area of Bayelsa State. The larvae were kept in a plastic container and convey to the Central Research Laboratory, Department of Chemical Sciences, Niger Delta University, Wilberforce Island, Bayelsa State, Nigeria. Upon preparation samples were washed thoroughly and rinsed with distilled water, and divided in three parts labelled raw, boiled and fried as shown in Figure 2, 3 and 4. The sample labelled boiled was put into aluminum pot containing $200 \mathrm{ml}$ of distilled water and boiled for $30 \mathrm{mins}$ on a stove at low temperature. The sample labelled fried was put into a frying pan containing $100 \mathrm{ml}$ of water and it was left to boil to dryness and the oil of the larvae was used to stir-fry it. $R$. phoenicis larvae were weighed before and after processing in order to calculate water lose.

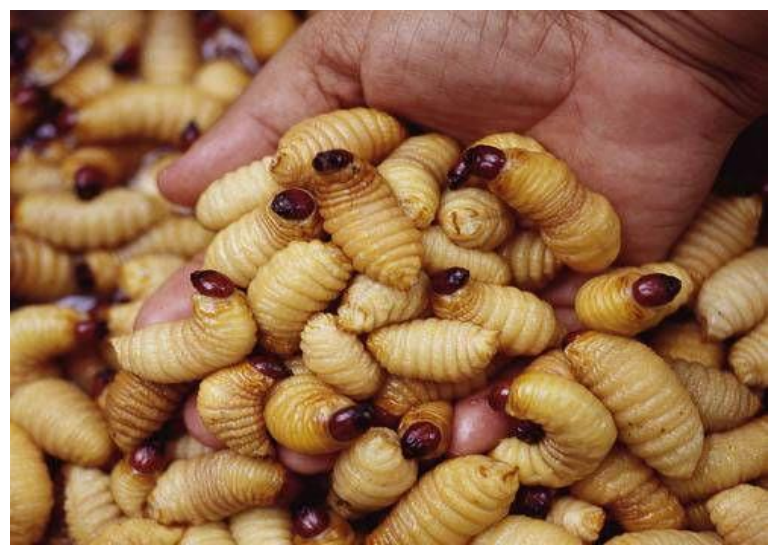

Fig. 2. Raw R. Phoenicis Larvae

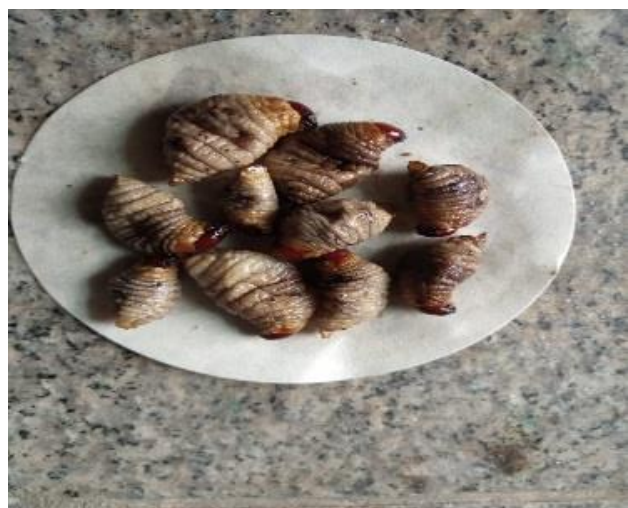

Fig 3. Boiled R. Phonenicis Larvae

Vol 2 | Issue 4 | August 2020 


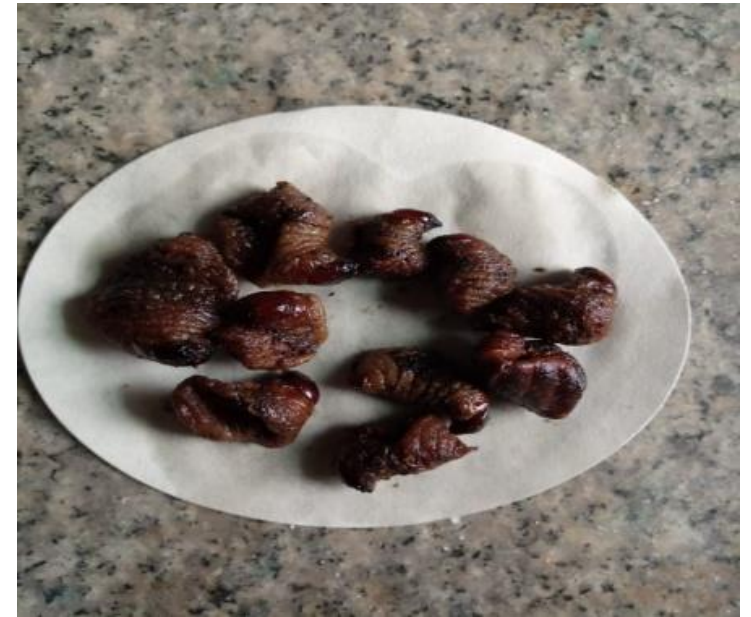

Fig. 4. Fried R. Phoneicis Larvae

\section{Proximate Analysis}

The percentage of the proximate composition of $R$. phoenicis larvae were determined using the conventional method of the Association of Official Analytical Chemists (AOAC) [15]. All chemical analysis were determined in triplicate.

\section{Determination of Moisture Content}

The initial weight of three (3) empty dishes labelled raw, boiled and fried were taken, and then three gram $(3 \mathrm{~g})$ of each sample (raw, boiled and fried) was weighed and placed on each dish as labelled. Samples were dried in an oven at $105^{\circ} \mathrm{C}$ to a constant weight for about three to five hours (35 hrs). Thereafter, the percentage moisture content for each sample was determined.

\section{E. Ash Content}

The ash content of a sample is the residue left after ashing in a furnace at about $550^{\circ} \mathrm{C}-600^{\circ} \mathrm{C}$ till the residue turn white or grey. In this study the ash content was determined by weighing three gram ( $3 \mathrm{~g}$ ) of the oven dried samples (raw, boiled and fried) into three different crucibles of known weight. The crucibles and contents were then placed in a vecstar furnace at $550^{\circ} \mathrm{C}$ for $1 \mathrm{hrs}$ and all the samples turn white. The percentages of ash was calculated by subtracting the ash weight from initial weight.

\section{F. Determination of Protein Content}

The protein content of raw, boiled and fried samples of $R$. phoenicis larvae were determined by Kjedahl methods [15]. This involves the conversion of protein and organic nitrogen to ammonium sulphate by digesting $0.5 \mathrm{~g}$ of the samples with concentrated sulphuric acid $\left(5 \mathrm{ml}\right.$ of conc. $\left.\mathrm{H}_{2} \mathrm{SO}_{4}\right)$ in a micro Kjedahl catalyst (1.5 $\mathrm{g} \mathrm{CuSO}_{4}$ and $\left.1.5 \mathrm{Na}_{2} \mathrm{SO}_{4}\right)$. The digest was then cooled and diluted with distilled water and treated with $10 \mathrm{ml}$ of $40 \% \mathrm{NaOH}$ and distilled in a Kjedahl distillation flash. The liberated ammonia was collected in a flash containing $10 \mathrm{ml}$ of $5 \%$ boric acid solution and the total nitrogen was determined titrimetrically. The percentage of protein in the samples were calculated using the 6.25 (gravimetric factor of protein).

\section{G. Determination of Fat Content}

The analysis of fat content was carried out by weighing approximately $5 \mathrm{~g}$ of each oven dried sample into a round bottom flash and extracted with $350 \mathrm{ml}$ petroleum ether. The extract was washed with diluted alkaline solution and filtered via sodium sulphate column. Then the remaining extract was evaporated, dried and weighed. Thereafter, the percentage fat was calculated.

\section{H. Determination of Fiber Content}

Crude fiber represents the organic residue left behind after a given material has been treated under standardized condition with light petroleum, boiling with dilute $\mathrm{H}_{2} \mathrm{SO}_{4}$, $\mathrm{NaOH}$ solution, $\mathrm{HCl}$, alcohol and ether. Thus, the fiber content of this study was determined by weighting approximately $1.5 \mathrm{~g}$ of defatted samples (raw, boiled and fried) in to three different beakers and boiled with $100 \mathrm{ml}$ of $\mathrm{H}_{2} \mathrm{SO}_{4}$ for 30mins. Thereafter, the residues were washed thoroughly with hot water till they were acid free. Again, each residue was boiled in $100 \mathrm{ml}$ of $\mathrm{NaOH}$ solution for $30 \mathrm{mins}$ and the content left were filtered and washed severally with hot water to free the base. Thereafter, the residues were dried and weighed and the percentage fiber of the samples were calculated.

\section{Determination of the Carbohydrate Content}

The total percentage $(\%)$ of carbohydrate content in the samples (raw, boiled and fried) were calculated by the standard equation $100 \%-(\%$ moisture $+\%$ protein $+\%$ fat + $\%$ fiber $+\%$ ash) .

\section{Results AND DisCUSSION}

\section{A. Proximate Composition}

The proximate composition of raw and processed $R$. phoenicis larvae are very important to determine their nutritional value in conformity to the range of dietary requirements and commercial specification set by regulatory bodies for food products. The proximate composition (moisture, ash, protein, total lipid, crude fiber and carbohydrate contents) of raw and processed $R$. phoenicis larvae are presented in Table 1.

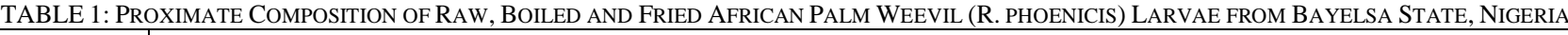

\begin{tabular}{|c|c|c|c|c|c|c|}
\hline \multirow{2}{*}{$\begin{array}{c}\text { Sample } \\
\text { R. phoenicis) }\end{array}$} & \multicolumn{7}{|c|}{ Proximate Composition } & Fiber (\%) & Protein (\%) & Carbohydrate (\%) \\
\cline { 2 - 7 } & Moisture (\%) & Ash (\%) & Fat (\%) & $14.50 \pm 0.71$ & $26.25 \pm 0.01$ & $66.89 \pm 0.42$ \\
\hline Raw & $59.50 \pm 0.71$ & $6.29 \pm 0.06$ & $60.35 \pm 0.07$ & $8.66 \pm 0.06$ & $25.08 \pm 0.02$ & $62.85 \pm 0.04$ \\
\hline Boiled & $65.50 \pm 0.71$ & $9.36 \pm 0.02$ & $54.25 \pm 0.07$ & $11.29 \pm 0.06$ & $31.53 \pm 0.68$ & $49.11 \pm 0.28$ \\
\hline Fried & $44.50 \pm 0.71$ & $13.29 \pm 0.06$ & $48.50 \pm 0.71$ &
\end{tabular}




\section{B. Moisture Content}

Table 1 showed that the proximate composition of $R$. phoenicis larvae was significantly influenced by the culinary methods (boiling and frying). The moisture content for raw, boiled and fried were $59.50 \pm 0.71 \%, 65.50 \pm 0.91 \%$ and $44.50 \pm 0.71 \%$ respectively. Boiling increased the moisture content of the larvae while frying reduced the moisture content. This can be attributed to the absorption of water by the larvae during boiling while reduction during frying is as a result of evaporation of water by the sample when frying at high temperature. The results of this study is similar to the findings of Bassey et al.,[16] which reported that, frying and grilling reduced the moisture content of three fish species collected from Nigerian coastal waters. Also, Marimuthu et al., [17] have reported a decrease in moisture content of all cooking methods except the boiled filters of striped snakehead fish. The reduction in moisture content is advantageous as it could lead to reduction in the larvae susceptibility to microbial spoilage, oxidative degradation of poly unsaturated fatty acid, and conversely improves the quality of the larvae especially for longer preservation [18].

\section{Ash Content}

The results in table 1 also shows that the ash content of the larvae was influenced by the culinary methods. The ash content was in the decreasing order of fried $(13.29 \pm 0.06 \%)$ $>$ boiled $(9.36 \pm 0.02 \%)>$ raw $(6.29 \pm 0.06 \%)$. Generally, the ash content or residue indicates a measure of the mineral content of the original food [19]. Therefore, the increase in ash content during processing (frying and boiling) indicated an increase in the mineral content of the larvae. Similarly, Bassey et al.,[16], reported an increase in ash content during boiling, grilling and frying in three Nigerian fish species namely; $C$. senegalenis, $C$. nigrodigitatus and $P$. quadratifilis. The percentage increase of the processing methods were in the order of frying $>$ grilling $>$ boiling respectively. Also, Ersoy and Ozeren [20] reported that, frying and grilling led to significant increase in the ash content of African catfish.

\section{Protein Content}

The protein content of the edible larvae ( $R$. phoenicis) increased in the order of fried $(31.53 \pm 0.6 \%)>$ raw $(26.25$ $\pm 0.01 \%)>$ boiled $(25.08 \pm 0.02 \%)$. Studies have shown that, loss of moisture content could simultaneously increase the protein content of biota [16],[21] - [23]. Roksana et al.,[24] have also observed similar trend that, loss of moisture content led to a significant increase in the protein content in boiled silver pomfret fish compared to the raw samples. Therefore, in this study, frying had the greatest moisture losses compared to boiled and the raw sample showed the highest protein content.

\section{E. Fat Content}

The fat content of the larvae shows a significant difference $(\mathrm{p}<0.05)$ in order of raw $(60.35 \pm 0.07 \%)>$ boiled $(54.25 \pm 0.07 \%)>$ fried $(48.50 \pm 0.71 \%)$. The reduction of fat during boiling and frying could be related to loss of oil and evaporation of water, and the fat content in the fried sample was significantly reduced $(p>0.05)$. The result of fat content in the boiled sample is contrary to the findings of Bassey et al.,[16] in three fish species from Nigerian coastal waters.

\section{F. Crude Fiber Content}

Theoretically, crude fiber content is the materials that are indigestible in human and animal systems and the indigestible fraction could be successively isolated via acid and alkaline digestion. However, crude fibre do not actually measure the real percentage of the food that is unavailable to man because during chemical treatments (e.g acid and alkaline digestion) crude fibre estimation, a greater loss in fibre materials take place [25].

In this study, the culinary methods (boiling and frying) significantly affect the fibre content of the edible insect $(R$. phoenicis) larvae. The fibre content was in the decreasing fibre order of raw $(14.50 \pm 0.71 \%)>$ fried $(11.29 \pm 0.06 \%)$ $>$ boiled $(8.66 \pm 0.06 \%)$. The reduction of fibre content of the boiled and fried sample may be due to the loss of chemical components (such as cellulose, hemicellulose, pectic substance, gums, mucilage or ligin) of one or more dietary fibre or the alteration of some structural functionality of the fibre content in the sample [26]. The reduction of fibre content in this study corresponds to the findings of Vidal-Valverde et al., [27] which reported that, cooking reduced the fibre content of lentils due to decrease in hemicellulose. Likewise, Thed and Philips, [28] reported that, microwave heating and deep fat frying of potato products led to reduction of appreciable amount in vitro digestible starch but significantly increased both the resistant starch (RS) and water-insoluble dietary fibre (IDF) due to indigestible starch (dietary fibre) formed by the action.

Diets with high fibre content such as cereals, fruits and vegetables have been known to performed various therapeutic functions which includes; large volume of fecal bulk, decreasing time of intestinal transit, reliefs of constipation, cholesterol and glycemic levels, trapping of substances that can be dangerous to the human health (mutagenic and carcinogenic agents), stimulating the proliferation of the intestinal flora etc [29]. Therefore, the raw sample with the highest fibre content $(14.50 \pm 0.71 \%)$ would be more suitable in terms of fibre consumption.

\section{G. Carbohydrate Content}

The carbohydrate content was determined in order to know the total energy content of this edible insect larvae. The carbohydrate content were in the order of raw $(66.89 \pm$ $0.42 \%)>$ boiled $(62.85 \pm 0.04 \%)>$ fried $(49.11 \pm 0.28 \%)$ respectively. The culinary methods significantly decreased the percentage carbohydrate content and the fried sample ranked the lowest value of $49.11 \pm 0.28 \%$. However, the high carbohydrate content in these larvae indicate their suitability as a good source of energy to consumers.

TABLE 2: COMPARISON OF THE EFFECTS OF DIFFERENT CULINARY METHODS ON THE PROXIMATE COMPOSITION OF R. PHOENICIS AND OTHER FISH PRODUCTS 


\begin{tabular}{|c|c|c|c|c|c|c|c|}
\hline \multirow[b]{2}{*}{ Sample } & \multicolumn{6}{|c|}{ Percentage Proximate Composition } & \multirow[b]{2}{*}{ References } \\
\hline & $\begin{array}{l}\text { Culinary } \\
\text { methods }\end{array}$ & $\begin{array}{c}\text { Moisture } \\
(\%)\end{array}$ & $\operatorname{Ash}(\%)$ & Protein $(\%)$ & Fat $(\%)$ & $\begin{array}{c}\text { Carbohydrate } \\
(\%)\end{array}$ & \\
\hline \multirow{3}{*}{$\begin{array}{l}\text { African Palm } \\
\text { Weevil ( } R . \\
\text { phoenicis) }\end{array}$} & Raw & $59.50 \pm 0.71$ & $6.29 \pm 0.06$ & $26.25 \pm 0.01$ & $60.35 \pm 0.07$ & $66.89 \pm 0.42$ & \multirow{3}{*}{ This study } \\
\hline & Boiled & $65.50 \pm 0.71$ & $9.36 \pm 0.02$ & $25.08 \pm 0.02$ & $54.25 \pm 0.07$ & $62.85 \pm 0.04$ & \\
\hline & Fried & $44.50 \pm 0.71$ & $13.29 \pm 0.06$ & $31.53 \pm 0.68$ & $48.50 \pm 0.71$ & $49.11 \pm 0.28$ & \\
\hline \multirow{4}{*}{$\begin{array}{l}\text { Polydactylus } \\
\text { quadratifilis }\end{array}$} & Raw & $77.00 \pm 3.60$ & $1.28 \pm 0.07$ & $15.79 \pm 1.23$ & $4.08 \pm 0.21$ & 1.85 & \multirow{12}{*}[16]{} \\
\hline & Boiled & $72.50 \pm 2.78$ & $1.47 \pm 0.12$ & $17.86 \pm 0.86$ & $4.26 \pm 0.10$ & 3.91 & \\
\hline & Grilled & $61.47 \pm 2.54$ & $2.25 \pm 0.11$ & $28.05 \pm 1.99$ & $6.31 \pm 0.15$ & 1.92 & \\
\hline & Fried & $56.33 \pm 3.04$ & $2.40 \pm 0.13$ & $34.93 \pm 1.30$ & $7.35 \pm 0.14$ & 0.00 & \\
\hline \multirow{4}{*}{$\begin{array}{l}\text { Chrysicthys } \\
\text { Nigrodigitatus }\end{array}$} & Raw & $74.47 \pm 0.98$ & $1.28 \pm 0.04$ & $12.10 \pm 1.28$ & $4.29 \pm 0.25$ & 7.86 & \\
\hline & Boiled & $71.27 \pm 1.37$ & $1.64 \pm 0.06$ & $17.10 \pm 1.57$ & $4.50 \pm 0.65$ & 5.49 & \\
\hline & Grilled & $58.00 \pm 2.08$ & $4.03 \pm 0.12$ & $24.36 \pm 0.45$ & $6.37 \pm 0.75$ & 7.24 & \\
\hline & Fried & $51.40 \pm 3.23$ & $4.23 \pm 0.13$ & $26.61 \pm 0.88$ & $8.12 \pm 0.61$ & 10.41 & \\
\hline \multirow{4}{*}{$\begin{array}{l}\text { Cynoglossue } \\
\text { senegalensis }\end{array}$} & Raw & $77.40 \pm 1.71$ & $17.61 \pm 0.11$ & $17.61 \pm 1.93$ & $3.35 \pm 0.19$ & 1.09 & \\
\hline & Boiled & $71.33 \pm 0.94$ & $1.69 \pm 0.11$ & $20.68 \pm 1.68$ & $3.99 \pm 0.27$ & 2.31 & \\
\hline & Grilled & $61.70 \pm 2.04$ & $3.27 \pm 0.17$ & $24.20 \pm 0.88$ & $6.10 \pm 0.63$ & 4.28 & \\
\hline & Fried & $56.97 \pm 2.01$ & $4.18 \pm 0.14$ & $28.66 \pm 2.91$ & $7.49 \pm 0.28$ & 2.70 & \\
\hline \multirow{5}{*}{$\begin{array}{c}\text { Snake head fish } \\
\text { (Channa striatus) } \\
\text { striped }\end{array}$} & Raw & $77.20 \pm 1.39$ & $0.77 \pm 0.12$ & $13.90 \pm 2.89$ & $5.90 \pm 0.45$ & - & \multirow{5}{*}{ [17] } \\
\hline & Boiled & $77.00 \pm 0.31$ & $1.10 \pm 0.13$ & $15.20 \pm 0.96$ & $6.10 \pm 1.40$ & - & \\
\hline & Baked & $74.90 \pm 0.33$ & $1.30 \pm 0.12$ & $14.20 \pm 1.82$ & $7.80 \pm 0.39$ & - & \\
\hline & Fried & $71.60 \pm 1.48$ & $1.60 \pm 0.13$ & $17.30 \pm 1.26$ & $10.70 \pm 1.85$ & - & \\
\hline & Grilled & $72.00 \pm 0.53$ & $1.7 \pm 0.15$ & $16.10 \pm 0.10$ & $8.60 \pm 0.67$ & - & \\
\hline \multirow{5}{*}{$\begin{array}{c}\text { Black sea Anchovy } \\
\text { (Engraulis } \\
\text { encrasicolus, } \\
\text { linnaeus } 1758\end{array}$} & Raw & $62.85 \pm 0.03$ & $1.48 \pm 0.01$ & $22.71 \pm 0.04$ & & & \multirow{5}{*}{ [23] } \\
\hline & Grilled & $54.63 \pm 0.07$ & $1.97 \pm 0.00$ & $25.55 \pm 0.16$ & $17.51 \pm 0.19$ & & \\
\hline & Baked & $52.83 \pm 0.03$ & $1.32 \pm 0.01$ & $22.58 \pm 0.10$ & $20.54 \pm 0.13$ & & \\
\hline & Fried & $49.55 \pm 0.08$ & $2.02 \pm 0.01$ & $24.44 \pm 0.16$ & $23.30 \pm 0.09$ & & \\
\hline & $\begin{array}{c}\text { Microwave } \\
\text { cooked }\end{array}$ & $52.50 \pm 0.06$ & $1.82 \pm 0.00$ & $22.63 \pm 0.09$ & $22.34 \pm 0.18$ & & \\
\hline \multirow{6}{*}{$\begin{array}{l}\text { Rainbow trout fish } \\
\text { (oncorhynchynchas } \\
\text { mykiss walbaum }\end{array}$} & Raw & $73.38 \pm 0.02$ & $1.35 \pm 0.01$ & $19.80 \pm 0.04$ & $3.44 \pm 0.01$ & - & \multirow{6}{*}[21]{} \\
\hline & Fried & $62.69 \pm 0.02$ & $1.66 \pm 0.01$ & $26.34 \pm 0.23$ & $12.70 \pm 0.08$ & - & \\
\hline & Boiled & $69.16 \pm 0.04$ & $1.61 \pm 0.03$ & $20.66 \pm 0.67$ & $4.32 \pm 0.75$ & - & \\
\hline & Baked & $65.83 \pm 0.07$ & $1.41 \pm 0.00$ & $23.26 \pm 0.00$ & $6.21 \pm 0.43$ & - & \\
\hline & Grilled & $65.83 \pm 0.05$ & $1.54 \pm 0.03$ & $25.00 \pm 0.41$ & $5.95 \pm 1.49$ & - & \\
\hline & $\begin{array}{c}\text { Microwave- } \\
\text { cooked }\end{array}$ & $63.52 \pm 0.08$ & $1.53 \pm 0.01$ & $29.04 \pm 0.48$ & $4.52 \pm 0.06$ & - & \\
\hline
\end{tabular}




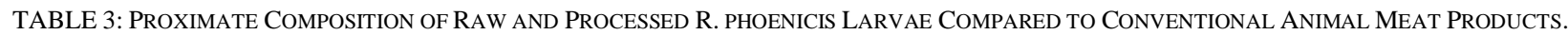

\begin{tabular}{|c|c|c|c|c|c|c|c|}
\hline \multirow[b]{2}{*}{$\mathbf{S} / \mathbf{N}$} & \multicolumn{7}{|c|}{ Proximate composition (\%) } \\
\hline & Sample & Carbohydrate $\%$ & Protein $\%$ & Fat $\%$ & Ash \% & Moisture \% & Reference \\
\hline $\mathrm{I}$ & R. phonecis larvae & 66.89 & 26.25 & 60.35 & 6.29 & 59.50 & \multirow{16}{*}[30]{,$[31]}$. \\
\hline II & Snail meat & 2.93 & 20.70 & 1.21 & 1.49 & 73.67 & \\
\hline III & Beef & - & 17.50 & 22.00 & 0.90 & 60.00 & \\
\hline (a) & Pork & - & 11.19 & 45.00 & 0.60 & 42.00 & \\
\hline $\begin{array}{l}\text { (b) } \\
\text { (c) }\end{array}$ & Lamb & - & 15.70 & 27.70 & 0.80 & 56.00 & \\
\hline \multirow{5}{*}{$\begin{array}{l}\text { IV } \\
\text { (a) } \\
\text { (b) } \\
\text { (c) } \\
\text { (d) }\end{array}$} & Poultry & & & & & & \\
\hline & Chicken & - & 20.20 & 12.60 & 1.00 & 81.80 & \\
\hline & Duck & - & 16.20 & 30.00 & 1.00 & 68.60 & \\
\hline & Turkey & - & 20.20 & 20.20 & 1.00 & 79.30 & \\
\hline & Dried fish & - & 60.00 & 21.00 & 15.00 & 4.00 & \\
\hline \multirow{3}{*}{$\begin{array}{l}\mathrm{V} \\
\text { (a) } \\
\text { (b) }\end{array}$} & Milk & & & & & & \\
\hline & Cow (whole milk) & 5.00 & 3.50 & 3.80 & 0.70 & 87.30 & \\
\hline & Goat & 4.50 & 3.80 & 4.80 & 0.80 & 86.40 & \\
\hline $\begin{array}{l}\text { VI } \\
\text { (a) }\end{array}$ & Eggs & & & & & - & \\
\hline \multirow[t]{2}{*}{ (b) } & $\begin{array}{l}\text { White of egg small } \\
\text { amount }\end{array}$ & 10.50 & Small amount & 1.00 & 88.00 & & \\
\hline & $\begin{array}{l}\text { Yolk of egg small } \\
\text { amount }\end{array}$ & 15.50 & 33.50 & 1.00 & 49.50 & - & \\
\hline
\end{tabular}

\section{CONCLUSION}

The proximate composition of the edible insect commonly known as African palm weevil (R. phoenicis) larvae revealed the basic nutrient requirements (such as proteins, minerals, fat, fibre and carbohydrate) for healthy diet. Literature search in the study also revealed that the nutritional value of this edible insect larvae could compete favourably with the conventional animal and fish products. However, the common culinary methods (boiling and frying) had a significant influence on the proximate composition of the larvae. For example, boiling increased the moisture and ash contents but decreased the protein, fat, fibre and carbohydrate contents of the larvae. While frying increased the protein and ash contents but, decreased the moisture, fat, fibre and carbohydrate contents as compared to the raw sample. The decrease in moisture content led to a corresponding increase in the ash and protein contents of the larvae in the fried sample, and these are the main nutrients in food. Although high heat during frying may cause denaturation of proteins but the amino acid content is retained [32]. Thus, the lowest fat, and moisture contents which minimize spoilage by reducing microbial activities would enhance shelf life of the larvae for longer storage. The highest protein and the ash content were found in the fried samples. Therefore, frying could be recommended as the best culinary method for the preparation of $R$. phoenicis larvae for healthy diet.

\section{ACKNOWLEDGEMENT}

The authors are grateful to the management of the Central Research Laboratory and the Department of Chemical Sciences, Faculty of Science, Niger Delta University, Wilberforce Island, Bayelsa State for the released of reagents and facilities for completion of this research work.

\section{REFERENCES}

[1] V.H. Arnold, V.I.Joost, K. Harmke, M. Esther, H. Afton, M. Gulia and V. Paul, "Edible Insects; Future Prospects for Food and Feed Security", Food and Agriculture Organization of the United Nations Rome, 2013. FAO, Forestry Paper, 171: pp 1-29, 2013.

[2] S. Boulidam, "Edible Insects in Lao Market Economy", In Durst P.B., D.V. Johnson, R.L. Leslie, and K. Shono, Forest Insects as Food. Human Bite Back, Proceedings of a Workshop on Asia-Pacific Resources and their Potential for Development. Bangkok, Thailand, FAO Regional Office for Asia and the Pacific, Pp. 131-140. 2010.

[3] V. Melo.,M. Garcia, H. Sandoval, H.D. Jimenez, C. Calvo, "Quality Proteins from Edible indigenous Insect Food of Latin America and Asia", Emirates J. Food Agric., 23, 283-289, 2011.

[4] FAO, "Biodiversity and Nutrition, a common path", Rome, 2009b.

[5] L. Yong-woo.,"Silk Reeling and Testing Manuel", FAO Agricultural Services Bulletin, 136,1999.

[6] T. Ekrakene, and C.L. Igeleke, "Microbial Isolates from the Roasted Larvae of the Palm Weevil (Rhynchophorus phoenicis) from Edo and Delta States of Nigeria”, Ama J. Biol. Applied Sci., 1 763-768, 2009.

[7] C.C. Okaraonye, and J.C. Ikewuchi, "Rhynchoporus phoenicis larvae Meal: Nutritional Value and Health Implication",Journal of Biological Sciences, 8 (7), 1221-1225, 2008.

[8] B.O. Elemo, G.N. Elemo, M.A. Makinde, and O.L. Erukainure, "Chemical Evaluation of African Palm Weevil, Rhychophorus phoenics larvae as a food source",Journal of Insect Science, 11: 146, 2011.

[9] O.T. Omotoso, and C.O. Adedire, "Nutrient Composition, Mineral Content and Solubility of the Proteins of Palm Weevil Rhynchophorus phoenicis (Coleoptera, Curculianidae)",Journal of Zhejiang University, Science. B., 8 (5), 318-322,2007.

[10] R.A. Oluwo, B.A. Moronkola, O.O. Tovids, A.A. Denloye, K.N. Awokoya, C.E. Sunday, and M.D.O. Oluji, "Assessment of Proximate and Mineral Status of Rhinoceros Beetle Larvae, Orytces rhinoceros Linnaeus (1758) Coleoptera scarabaeidae from Itokin, Lagos State, Nigeria",Journal of Environment Sciences, 6, 118-124, 2012.

[11] W.O. Okunowo, A.M. Olagboye, L.O. Afolabi, and A.O. Oyedeji, "Nutritional Value of Rhynchophorus phoenicis (F) larvae, an edible Insect in Nigeria",African Entomology, 257(1), 2017.

[12] M.B. Achu, K.B. Loh, N. Yisa, and S.M.M. Kana, "Preliminary Proximate Composition and Mineral Contents of five edible Insects from Cameroon",Int. J. Curr. Microbial. App. Sci., 6 (3). 1984-1995, 2017.

[13] O.T. Omotoso, "The Nutrient Profile of the Developmental Stages of Palm Beetle, Orytees rhinoceros L",British Journal of Environmental Science, 6 (1). 1-11, 2018. 
[14] E.N. Ogamba, S.C. Izah, and T. Oribu, "Water Quality and Proximate Analysis of Eichnornia Crassipes from River Nun, Amassoma Axis, Nigeria",Research Journal of Phytomedicine, 1, 43-48, 2015a.

[15] Association of Official Analytical Chemists (AOAC), "Official Methods of Analysis of AOAC", Washington, D.C. USA, $17^{\text {th }}$ edition, 2000.

[16] F.L. Bassey, F.C. Oguntude, C.M.A Iwegbu,V.N. Osabor, and C.A. Edem, "Effects of Processing on the Proximate and Metal Contents in Three Fish Species from Nigerian Coastal Waters",Journal of Food Science and Nutrition, 2 (3), 272-281, 2014.

[17] K. Marimuthu, M.Thilaga, S. Kathiresan, R. Xavier, and R.H.M.H Mas, "Effect of Different Cooking Methods on Proximate and Mineral Composition of Striped Snakehead fish (Channa striatus, Bloch)", Journal of Food Science and Technology, 49(3), 373-377, 2012.

[18] E.N. Frankel., "Recent Advances in Lipids oxidation",J. Sci. Food Agric., 54, 495-511, 1991.

[19] R.S. Kirk, and R. Sawyer, "Pearson's Composition and Analysis of Foods", $9^{\text {th }}$ edition. Longman Scientific and Technical, Essex, England, 1991.

[20] B. Ersoy, and A. Ozeren, "The Effect of Cooking Methods on Mineral and Vitamin Contents of African Catfish", Food Chem., 115, 419422, 2009.

[21] N. Gokugalu, P. Yerlikaya, and E. Cengiz, "Effects of Cooking Methods on the Proximate Composition and Mineral Contents of Rainbow Trout (Oncorchynchus mykiss)",Food Chem., 84, 19-22, 2004.

[22] A.O. Musaiger, and R.D. D'Souza, "The Effects of Different Methods of Cooking on Proximate Mineral and Heavy Metal Composition of Fish and Shrimps Consumed in the Arabian Gulf', Arch. Latinoam. Nutri., 58, 103-109, 2008.

[23] D. Kocatepe, H. Turan, G. Taskagy, Y. Kaya, R. Erden, and F. Erdogudu, "Effects of Cooking Methods on the Proximate Composition of Black Sea Anchovy (Engraulis encrasicolus, Linnaeus 1758)", GIDA, 36, 71-75, 2011.

[24] H. Roksana, M.M. Kamruzzaman, K. Afifa, I. Mahfuza, H. Afzal, H. Arzina, Shirin Jamiul, N.J. Yeasmin, and I. Ashraful, "Comparative Study of Raw and Boiled Silver Pomfret Fish from Coastal Area and Retail Market in Relation to Trace Metals and Proximate Composition",International Journal of Food Science,2014. ID 826139. http://dx.doi.org/10.1155/826139.

[25] D. Devinder, M. Mona, and R.T. Patil, "Dietary Fibre in Foods" A Review. J. Food Sci. Technology, 49(3), 255-266, 2012.

[26] F. Guillon, and M. Champ, "Structural and Physical Properties of Dietary Fibres and Consequences of Processing on Human Physiology",Food Res. Int., 33, 233-245, 2000.

[27] C. Vidal-Valverda, J. Frias, and R. Esteban, "Dietary Fibre in Processed Lenths", J.S. Food Sci., 57, 1161-1163, 1992.

[28] S.T. Thed, and R.D. Philips, "Changes of Dietary Fibre and Starch Composition of Processed Potato Products During Domestic Cooking",Food Chem., 52, 301-304, 1995

[29] G.R. Beecher, "Phytonutrients role in Metabolism: Effects on resistance to degenerative processes",Nutr Rev., 57, 3-6, 1999.

[30] I.O. Wosu, "Commercial Snail Farming in West Africa: A Guide", AP Express Publishers Ltd, Nsukka, 2003.

[31] O.M. Agbogidi, and B.L. Okonta, "Reducing Poverty through Snail Farming in Nigeria",Agriculture and Biology Journal of North America, 2(1), 169-172, 2011.

[32] A. Morris, A. Barnett, O.J. Burrows, "Effect of Processing on Nutrient Content of Foods", Cajarticle, 37(3), 16,2004. (http:/amro.who.int/English/CFN/cfni-caj37No 304.art-3-pdf).

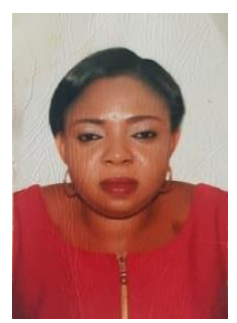

Dr. (Mrs.) Douye Parkinson Markmanuel was born on $13^{\text {th }}$ February, 1978 in Agudama-Epie, Yenagoa, Bayelsa State, Nigeria. She attended St. Luke's Primary School, 1983-1990 and Community Secondary School, 1991-1996 in Agudama-Epie where she obtained her First School Leaving Certificate (FLSC), and West African Senior School Certificate (WASSC). She obtained Bachelor of Education Degree (B.ED) in Chemistry (2 ${ }^{\text {nd }}$ Class Upper) in 2002 at University of Ibadan, Master of Science (M.Sc) Degree 2011 and Doctor of Philosophy (Ph.D), 2016 in Pure and Industrial Chemistry (Environmental Chemistry) from the University of Port Harcourt, River State.
She was first employed as a MASTER GRADE II Teacher in Bayelsa State College of Arts and Science Model Secondary School in 2005 and later transferred to the main college in 2006 where she was upgraded to the rank of INSTRUCTOR in Department of Science and Technology. Upon the conversion of the College of Arts and Science to the College of Education, she was made ASSISTANT LECTURER, and later rose to the rank of LECTURER I, where she served as the Pioneer Acting Head of the Department of Integrated Science, 2013-2015, Acting Head of Chemistry Department, 2016-2017. However, in December 2017, she moves her service to the Niger Delta University, where she is currently serving as LECTURER I in the Department of Chemical Sciences. She is also serving as a CONSULTANTS to Winners International Academy, Agudama-Epie, on Academics and Curriculum Development in Science and Technology. She has authored several publications in both local and international journals. Example;

- Markmanuel D.P., Young E., and Godwin J. The Effects of Processing on Heavy Metals Concentration and Health Risk Assessment in African Palm Weevil (Rhynchophorusphoenicis) larvae.Toxi App pharInsig, Vol.3 (1), PP 1-5), 2020.

- Markmanuel, D.P., Adowei P., and Young E. Speciation and Human Health Risks Evaluation of Nickel and Cadmium in Land and Marine Snails from Bayelsa State, Nigeria. IJMPR, 3(6), 94-103, 2019.

- Douye P.M., Donbebe S.W., and Tarawou T. Health Risk of Lead Poisoning in Four Edible Snail Samples obtained from Bayelsa State, Nigeria. Vol. 8(1) PP 1-12. Her current research is centred on Heavy Metal Speciation on Edible Biota and Health Implication.

Dr. (Mrs.) Douye P. Markmanuel has served in several professional bodies and held several positions. Vice President, Women in Colleges of Education (2014-2017), Member, World Organization for Early Childhood Education (OMEP), Treasurer (2015-2019), Vice Chairman (2019 till date), Nigerian Environmental Society, Bayelsa State Chapter, Financial Secretary Chemical Society of Nigeria, Bayelsa State Chapter, 2018 till date, Member, Institute of Charted Chemists of Nigeria, 2007 till date. Member, the Nigerian Girls Guide Association. She is also a recipient of the Chartered Fellowship Award as "Eminent Peace Ambassador" 2017 of the International Association of World Peace Advocate, United Nation Peace Volunteers, and awardee of the Nigerian Girls Guide Association "Commendation Award", Eastern Zone, Nigeria". 